Erratum Open Access

\title{
Microbial Community Dysbiosis and Functional Gene Content Changes in Apple Flowers due to Fire Blight
}

\section{Hyun Gi Kong*, Hyeonheui Ham, Mi-Hyun Lee, Dong Suk Park, and Yong Hwan Lee}

Crop Protection Division, National Institute of Agricultural Sciences, Rural Development Administration, Wanju 54875, Korea

https://doi.org/10.5423/PPJ.NT.05.2021.0072

Plant Pathol. J. 37(4) : 404-412 (2021)

The part that needs to be corrected is to change the positions of the D and $\mathrm{H}$ labels in Figure 3A.

\section{Original version}

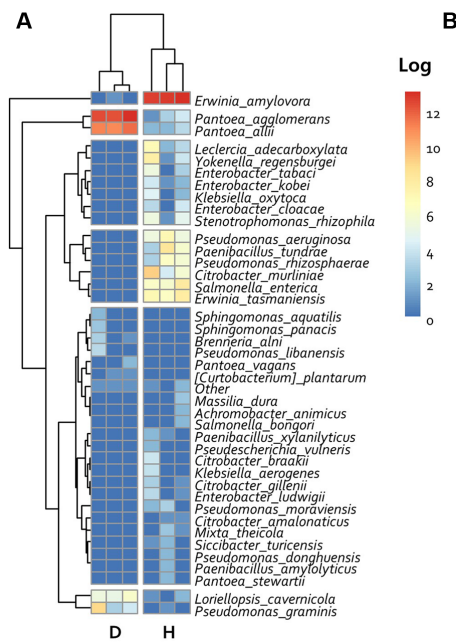

B

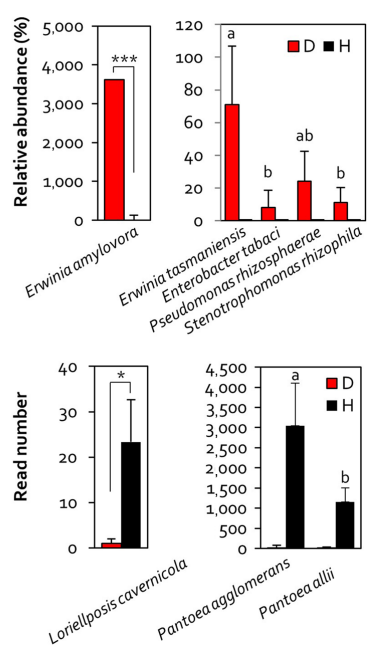

\section{Corrected version}

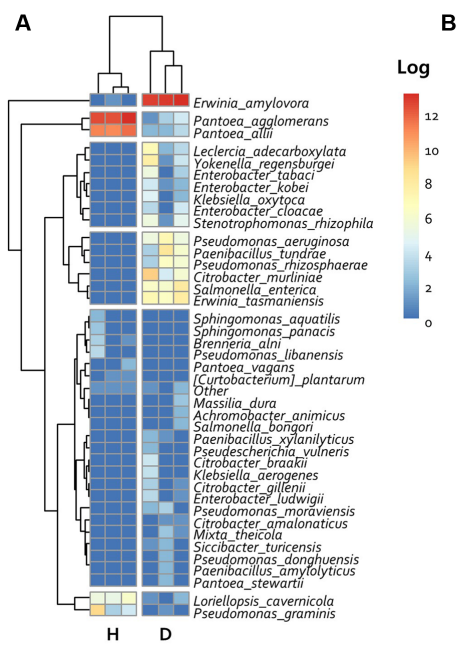

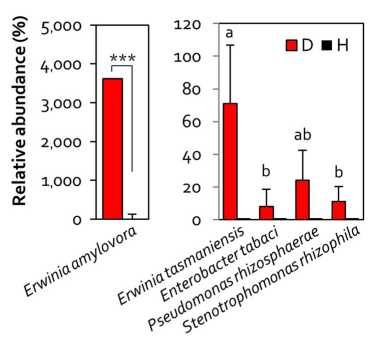

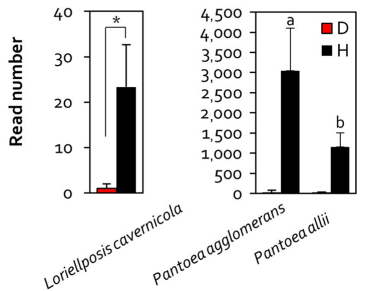

*Corresponding author.

Phone) +82-63-238-3279, FAX) +82-63-238-3838

E-mail)khgidea@korea.kr

(c) This is an Open Access article distributed under the terms of the Creative Commons Attribution Non-Commercial License (http://creativecommons.org/licenses/by-nc/4.0) which permits unrestricted noncommercial use, distribution, and reproduction in any medium, provided the original work is properly cited.

Articles can be freely viewed online at www.ppjonline.org. 